\title{
Diagnosis of macrosocial risks of drug use in Mexican municipalities
}

\author{
Solveig E. Rodríguez-Kuri, $R a u ́ l ~ G a r c i ́ a-A u r r e c o e c h e a,{ }^{2}$ José Luis Benítez-Villa, ${ }^{2}$ Carmen Fernández-Cáceres ${ }^{3}$
}

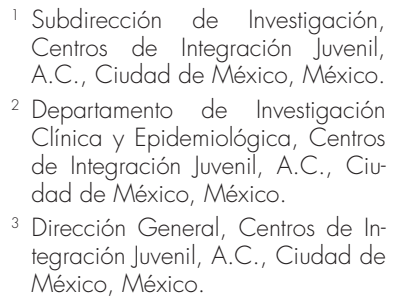

3 Dirección General, Centros de Integración Juvenil, A.C., Ciudad de México, México.

\section{Correspondence:}

Solveig E. Rodríguez Kuri

Subdirección de Investigación, Centros de Integración Juvenil, A.C.

Av. San Jerónimo 372, Col. del Pedre-

gal, Álvaro Obregón, 01900 Ciudad

de México, México.

Phone: +52 (55) 5999 - 4949

Email: solveig.rodriguez@cii.gob.mx

Received: 1 March 2018

Accepted: 28 November 2018

\section{Citation:}

Rodríguez-Kuri, S. E., García-Aurrecoechea, R., Benítez-Villa, J. L., Fernández Cáceres, C. (2019). Diagnosis of macrosocial risks of drug use in Mexican municipalities. Salud Mental, 42(1), 5-12

DOI: $10.17711 /$ SM.0185-3325.2019.002

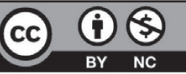

\begin{abstract}
Introduction. Factors associated with drug use are defined in terms of their proximity to the phenomenon and can be classified as individual, microsocial, and macrosocial. Macrosocial factors include variables of a geographic, economic, demographic, and social nature, which can be compiled from population censuses and surveys. Objective. To determine the levels of risk for drug use in municipalities in Mexico based on macro-social indicators. Method. Retrospective cross-sectional study, based on the analysis of population data, weighted by the Delphi method. Results. Sixty-four municipalities with a high or very high risk of drug use were identified. Factors such as the volume of drug seizures, prevalence of student use, alcohol supply, and inequality among the population were weighted as the factors with greatest risk for drug use. Discussion and conclusion. These data serve as a benchmark for guiding the efficient, rational administration of resources assigned for dealing with the problem of addictions, since they make it possible to identify localities with a greater need for care services.
\end{abstract}

Keywords: Risk factors, drug users, social determinants of health, mental health, Delphi technique, substance abuse.

\section{RESUMEN}

Introducción. Los factores asociados al consumo de drogas se definen en función de su proximidad con el fenómeno y pueden clasificarse en individuales, microsociales y macrosociales. Entre los factores macrosociales se incluyen variables de tipo geográfico, económico, demográfico y social, que es posible integrar a partir de censos y encuestas poblacionales. Objetivo. Determinar niveles de riesgo del consumo de drogas en municipios de la República Mexicana con base en indicadores macrosociales. Método. Estudio transversal retrospectivo, basado en el análisis de datos poblacionales, ponderados mediante el método Delphi. Resultados. Se identificaron 64 municipios con alto o muy alto riesgo de consumo de drogas. Factores como el volumen de decomisos de drogas, prevalencia de consumo en estudiantes, oferta de alcohol y desigualdad entre la población fueron ponderadas como los factores de mayor riesgo para el consumo de drogas. Discusión y conclusión. Estos datos representan un referente para orientar la administración eficiente y racional de los recursos destinados a atender el problema de las adicciones en tanto permiten identificar localidades que requieren servicios de atención con mayor prioridad.

Palabras clave: Factores de riesgo, usuarios de drogas, determinantes sociales de la salud, salud mental, técnica Delphi, abuso de sustancias. 


\section{INTRODUCTION}

Scientific literature describes a wide array of risk and protective factors associated with substance use. Some authors define them according to their level of proximity to the phenomenon, because of which these factors can be classified as macrosocial, microsocial, and individual (Hawkins, Catalano, \& Miller, 1992).

Macrosocial factors include economic, demographic and geographic variables, which affect the level of well-being of individuals. Another group of factors, the so-called microsocial factors, encompass aspects related to the subject's network of close relations, including those in the familial, school and work sphere, and with their partners and peers. Lastly, individual factors incorporate variables related to the person, which include aspects that ranging from self-esteem to the presence of affective or behavioral disorders.

According to Hawkins et al. (1992), the best way to develop effective strategies to prevent alcohol and drug use is precisely one that focuses on risk factors. In this respect, and from a macrosocial point of view, the population is exposed to very different risk conditions, depending on their geographical, economic, and social status. Thus, drug trafficking routes or areas with a high influx of tourists, for example, pose a significant risk of use, since they encourage greater supply and accessibility. Likewise, living in a locality with a significant migratory flow or high crime rates increases the risk of drug use (United Nations and International Drug Control Program, 1998; Santos \& Paiva, 2007; Zhang et al., 2015).

Nowadays it is possible to compile information on this type of indicators, based on the data provided by various government agencies drawn from the censuses and surveys undertaken periodically, whereby it is feasible to perform a diagnosis in macrosocial terms of the level of risk of drug use in the various communities in the country.

This can contribute to achieving a more efficient, rational administration of the resources assigned for addiction care, insofar as it makes it possible to identify localities with a greater need for these services.

Accordingly, since 1997, the Centros de Integración Juvenil (CIJ) have conducted a risk diagnosis of drug use in municipalities and delegations in Mexico on the basis of macrosocial indicators. This project constitutes a second update of the study, "Macrosocial risks of drug dependence at the municipal level and strategic care network in Mexico," published in 1997 (Salinas et al., 1997), and first updated in 2011 (García, Rodríguez, Córdova, \& Fernández, 2016). The results of these diagnoses have supported decision-making in the establishment of care units, at least at the CIJ, where three of the five units that have come into operation since the last study have been installed in municipalities classified as high-risk (García et al., 2016).

However, since drug use is a constantly changing phenomenon, it is necessary to periodically update its diag- nosis. This study has compiled information from various sources, in order to obtain an approach to the problem of drug use in the country from a macrosocial perspective, in addition to offering an updated benchmark for care needs at the municipal level. The purpose of this study was to determine Macrosocial Levels of Risk for Drug Use in the 426 municipalities and urban delegations (communities with over 50 inhabitants) in Mexico to provide a useful parameter to plan the establishment of care units in the country.

\section{METHOD}

\section{Type of study}

Retrospective, cross-sectional study, based on the analysis of census data and population surveys, weighted by means of assessment based on the Delphi technique.

\section{Procedure}

Based on a set of population, geographic, economic, human development, violence and supply, and use data for substances detailed below, a risk index of drug use was obtained for each municipality or delegation included in the study.

Since each indicator has a different importance in the risk of substance use, a method of assessment, known as the Delphi technique was used, in order to assess the importance of the various risk indicators considered.

\section{Delphi technique}

The Delphi technique is a method based on a panel of experts, which allows for the exchange and contrast of opinions and individual arguments on a topic in order to make consensual decisions (García \& Suárez, 2013). It is a method designed to obtain the opinion of a group of experts on a problem in a structured manner. The method incorporates a feedback exercise, which allows individual opinions to be brought closer to a consensus. This technique is especially useful when the available information is insufficient and requires the interpretation of specialists in the field (Boulkedid, Abdoul, Loustau, Sibony, \& Alberti, 2011). Moreover, this technique guarantees three fundamental aspects for collecting information when using instruments of this nature, namely confidentiality, controlled iteration/feedback, and the response of the group in statistical form (Awad-Núñez, González-Cancelas, \& Camarero-Orive, 2014).

\section{Participants}

The panel comprised 20 experts (11 women and nine men), whose professional career or work experience has provided them with extensive knowledge of the drug use problem and the associated risk and social conditioning factors asso- 
ciated with the latter, because of which they had sufficient elements to assess the importance of the macrosocial risk indicators considered in the study. The professional profile of the panel experts included mainly professionals in the field of health, such as psychologists, doctors, social workers, sociologists, and nurses with educational attainment corresponding to higher education or above. Most of them are affiliated to public or private organizations or institutions in the field of health, as well as teaching and research.

Given that the Delphi technique requires at least 15 judges to guarantee the validity of the consensus (Taylor-Powell, 2002) and due to the possibility of high attrition, 39 people were invited to participate to ensure that by the end of the survey and feedback process, there would be at least 15 judges. The panel of experts was eventually made up of 20 people, who encompassed the gamut of professional profiles mentioned above and completed the entire process. They were sent an email in which they were invited to participate in a survey on risk factors for drug use by answering questionnaire located in a virtual site, developed for this study, for which they were provided with an access link, as well as a username and password. They were asked to assign a score of zero to ten to each of the indicators listed, according to the importance they could have as risk factors for drug use among the inhabitants of a community.

Participants were told that two weeks after their first participation in the survey, they should return to the site where they would be informed of the result of the average weighting of all the judges. They were then asked to enter a discussion forum in which they could discuss the indicators with the lowest level of consensus, in other words, those with the most disparate ratings and the greatest deviation from the average. In addition, once they had expressed their opinions in the forum, they were asked to answer the questionnaire again, providing the grade they considered most appropriate, whether they decided to maintain the one they given in the first survey or chose to modify it, after finding out about the average grades and having participated in the discussion forum. The information gathering period ran from May 18 to 24, 2017, in its initial stage (first application of the questionnaire) and from May 30 to July 8 of the same year in the second stage (feedback, participation in the discussion forum, and second application of the questionnaire).

\section{Measurements}

Since the diagnostic studies that preceded the one presented here, the measurement indicators have shown variations since the conditions of the social context in which substance use takes place have also changed. Firstly, it should be noted that the number of urban municipalities in Mexico has altered with respect to the previous version of the study (García et al., 2016) because of demographic changes in Mexico, from 371 to 426 . Moreover, certain information sources are no longer available or the level of specificity of their data has changed, from having municipal to state representativity or from state to regional representativity, such as the National Addictions Survey, the 2011 version of which (Instituto Nacional de Psiquiatría Ramón de la Fuente Muñiz, Instituto Nacional de Salud Pública, \& Secretaría de Salud, 2012) contains data at the regional level, while the previous survey (Secretaría de Salud, 2009), which included state data, is already too outdated to be considered as a parameter in this diagnosis. Accordingly, it was decided to incorporate information from the Survey on Drug Use in Students (Instituto Nacional de Psiquiatría Ramón de la Fuente Muñiz, Comisión Nacional Contra las Addicciones, \& Secretaría de Salud, 2015) which presents state data and, athough it is not representative of the entire youth population of Mexico, it constitutes an important benchmark for substance use in the population enrolled in elementary (5th and 6th grades), middle and high school. Conversely, other sources have also emerged, more closely linked to the phenomenon that concerns us, which have been incorporated into this version.

Thus, whereas the last study included demographic, economic, geographical, educational, socio-familial, tourist influx and illegal drug production, and trafficking indicators, in this version of the study, indicators related to social violence have also been incorporated, as well as the number of nocturnal recreational spaces and those for alcohol sale and consumption.

In general, to undertake this diagnosis, efforts were made to incorporate indicators related to the drug use phenomenon in different ways. The following were therefore included: a) indicators directly related to use, such as survey data on the prevalence of use at the state level in the student population; b) factors that establish a more or less direct causal relationship, such as the presence of bars, canteens, and other establishments of this nature, which impact the supply of substances in localities; c) factors that imply an associative relationship, as in the case of indicators of violence and crimes which, although they do not maintain a causal relationship, may correlate with use; and d) structural factors, such as those related to demographic aspects, inequality, human development, etc., which, without having a linear relationship with substance use, may have a determinant effect on it.

Thus, eleven categories of indicators were considered: state prevalence of drug use, population, geographic, migration, education, employment, inequality and human development indicators, number of establishments for alcohol consumption, criminal activity and violence, seizures, and perception of sale and use of drugs. Table 1 provides a detailed list of Macrosocial Risk Indicators and their source.

\section{Analysis}

Once the risk rating for each indicator was obtained through the Delphi technique, and to prevent certain categories of 
Table 1

Risk indicators and weighted importance

\begin{tabular}{|c|c|c|c|c|c|}
\hline Category & Indicator & $\begin{array}{l}\text { Importance } \\
\text { weighted } \\
\text { by indicator }\end{array}$ & $\begin{array}{l}\text { Importance } \\
\text { weighted } \\
\text { by category }\end{array}$ & Justification of its inclusion & Sources \\
\hline \multirow{5}{*}{ Demographic } & $\begin{array}{l}\text { Urban concentration (propor- } \\
\text { tion of urban population of the } \\
\text { state living in that municipality) }\end{array}$ & 6.2 & \multirow{5}{*}{6.3} & \multirow{5}{*}{$\begin{array}{l}\text { Prevalence of drug use is } \\
\text { higher in urban areas and } \\
\text { among young males. } \\
\text { A high growth rate, as well } \\
\text { as living in a large city, } \\
\text { exposes people to a wide } \\
\text { array of direct and indirect } \\
\text { risks of using drugs. }\end{array}$} & $\begin{array}{l}\text { Encuesta Nacional de la } \\
\text { Dinámica Demográfica } 2014 \\
\text { (INEGI, 2014) }\end{array}$ \\
\hline & $\begin{array}{l}\text { Proportion of young people } \\
\text { (average age) }\end{array}$ & 6.4 & & & $\begin{array}{l}\text { Encuesta Intercensal, } 2015 . \\
\text { (INEGI, 2015) }\end{array}$ \\
\hline & $\begin{array}{l}\text { Proportion of male population } \\
(\%)\end{array}$ & 5.8 & & & $\begin{array}{l}\text { Censo de población y vivi- } \\
\text { enda, 2010. (INEGI, 2011) }\end{array}$ \\
\hline & $\begin{array}{l}\text { Average growth rate (percent- } \\
\text { age increase over 2010) }\end{array}$ & 6.2 & & & $\begin{array}{l}\text { Anuarios estadísticos es- } \\
\text { tatales 2009. (INEGI, 2010) }\end{array}$ \\
\hline & $\begin{array}{l}\text { Forms part of a metropolitan } \\
\text { area (yes - no) }\end{array}$ & 6.9 & & & $\begin{array}{l}\text { Delimitación de las zo- } \\
\text { nas metropolitanas, } 2010 . \\
\text { (CONAPO, SEDESOL, INE- } \\
\text { GI, 2010) }\end{array}$ \\
\hline \multirow[t]{2}{*}{ Geographical } & $\begin{array}{l}\text { Location on the northern bor- } \\
\text { der (border states yes - no) }\end{array}$ & 7.2 & \multirow[t]{2}{*}{7.2} & \multirow{2}{*}{$\begin{array}{l}\text { Some of the municipalities } \\
\text { with the highest prevalence } \\
\text { of drug use in the country } \\
\text { are located in states on } \\
\text { the northern border of the } \\
\text { country or constitute areas } \\
\text { with a significant tourist in- } \\
\text { flux. }\end{array}$} & $\begin{array}{l}\text { Resultados de la actividad } \\
\text { hotelera (Acumulados ene- } \\
\text { ro-diciembre 2016). (SEC- } \\
\text { TUR, Subsecretaría de Pla- } \\
\text { neación Turística, 2016). }\end{array}$ \\
\hline & $\begin{array}{l}\text { Tourist center (According to } \\
\text { SECTUR criteria yes - no) }\end{array}$ & 7.2 & & & $\begin{array}{l}\text { Diagnósticos Turísticos } \\
\text { Delegacionales 2014-2015. } \\
\text { (SECTUR-Ciudad de Méxi- } \\
\text { co, 2015). }\end{array}$ \\
\hline \multirow[t]{2}{*}{ Educational } & $\begin{array}{l}\text { Proportion of persons aged } 15 \\
\text { and over with no schooling (\%) }\end{array}$ & 6.5 & \multirow[t]{2}{*}{6.45} & \multirow{2}{*}{$\begin{array}{l}\text { Low educational attainment } \\
\text { is associated with a higher } \\
\text { risk of experimentation with } \\
\text { drug use. }\end{array}$} & \multirow{2}{*}{$\begin{array}{l}\text { Encuesta Intercensal, } 2015 . \\
\text { (INEGI, 2015) }\end{array}$} \\
\hline & Educational Attainment (years) & 6.4 & & & \\
\hline Night life & $\begin{array}{l}\text { Presence of nightclubs and } \\
\text { discos (No. of establishments) } \\
\text { Presence of bars, canteens } \\
\text { and alcohol outlets (No. of es- } \\
\text { tablishments) }\end{array}$ & 7.8 & 7.75 & $\begin{array}{l}\text { Places with an impact on } \\
\text { substance availability }\end{array}$ & $\begin{array}{l}\text { Directorio Estadístico Nacio- } \\
\text { nal de Unidades Económi- } \\
\text { cas, } 2016 \text { (INEGI, 2016). }\end{array}$ \\
\hline Migration & $\begin{array}{l}\text { Migration rate (Difference be- } \\
\text { tween number of emigrants } \\
\text { and immigrants) }\end{array}$ & 6.1 & 6.1 & $\begin{array}{l}\text { The mobility of the popu- } \\
\text { lation to another country } \\
\text { exposes them to a greater } \\
\text { acculturation stress, which } \\
\text { has been associated with } \\
\text { an increased risk of drug } \\
\text { use. }\end{array}$ & $\begin{array}{l}\text { Encuesta Nacional de la } \\
\text { Dinámica Demográfica } 2014 \\
\text { (INEGI, 2014) }\end{array}$ \\
\hline \multirow[t]{2}{*}{ Inequality } & $\begin{array}{l}\text { Human Development Index (0 } \\
\text { to 1) }\end{array}$ & 7.5 & \multirow[t]{2}{*}{7.5} & \multirow[t]{2}{*}{$\begin{array}{l}\text { Structural factors indirectly } \\
\text { related to drug use }\end{array}$} & $\begin{array}{l}\text { Indice de Desarrollo Hu- } \\
\text { mano en México. United } \\
\text { Nations Development Pro- } \\
\text { gram, } 2016\end{array}$ \\
\hline & Gini coefficient (0 to 1$)$ & 7.5 & & & $\begin{array}{l}\text { Consejo Nacional de Evalu- } \\
\text { ación de la Política de De- } \\
\text { sarrollo Social, } 2010\end{array}$ \\
\hline Unemployment & Unemployment level (\%) & 6.8 & 6.8 & $\begin{array}{l}\text { Like the inequality indexes, } \\
\text { it involves a structural fac- } \\
\text { tor related to drug use }\end{array}$ & $\begin{array}{l}\text { INEGI. Indicadores de ocu- } \\
\text { pación y empleo al segundo } \\
\text { trimestre de } 2017 \text {. }\end{array}$ \\
\hline \multirow{2}{*}{$\begin{array}{l}\text { Prevalence } \\
\text { of drug use in } \\
\text { students }\end{array}$} & $\begin{array}{l}\text { High prevalence of drug use } \\
\text { at least once in their lifetime } \\
\text { among middle school students } \\
(\%)\end{array}$ & 8.1 & \multirow{2}{*}{8.05} & \multirow{2}{*}{$\begin{array}{l}\text { These are direct indicators } \\
\text { of the risk of drug use in the } \\
\text { rest of the population }\end{array}$} & \multirow{2}{*}{$\begin{array}{l}\text { Encuesta Nacional del Con- } \\
\text { sumo de Drogas en Estudi- } \\
\text { antes, 2014. (INPRFM, CO- } \\
\text { NADIC, SSA, 2015) }\end{array}$} \\
\hline & $\begin{array}{l}\text { High prevalence of drug use } \\
\text { at least once in their lifetime } \\
\text { among high school students } \\
(\%)\end{array}$ & 8.0 & & & \\
\hline
\end{tabular}


Table 1

Risk indicators and weighted importance (continued)

\begin{tabular}{|c|c|c|c|c|c|}
\hline Category & Indicator & $\begin{array}{l}\text { Importance } \\
\text { weighted } \\
\text { by indicator }\end{array}$ & $\begin{array}{l}\text { Importance } \\
\text { weighted } \\
\text { by category }\end{array}$ & Justification of its inclusion & Sources \\
\hline \multirow{4}{*}{$\begin{array}{l}\text { Perception of sale } \\
\text { and use of drugs } \\
\text { and crimes in the } \\
\text { community }\end{array}$} & $\begin{array}{l}\text { Knowledge of alcohol con- } \\
\text { sumption ( } \% \text { of population that } \\
\text { reported having knowledge of } \\
\text { this situation) }\end{array}$ & 7.3 & \multirow{4}{*}{7.27} & \multirow{4}{*}{$\begin{array}{l}\text { It suggests a perception of } \\
\text { easy access to substances }\end{array}$} & \multirow{4}{*}{$\begin{array}{l}\text { Encuesta Nacional de Vic- } \\
\text { timización y Percepción } \\
\text { sobre Seguridad Pública, } \\
\text { 2016. (INEGI, 2016) }\end{array}$} \\
\hline & $\begin{array}{l}\text { Knowledge of drug use ( } \% \text { of } \\
\text { population that reported hav- } \\
\text { ing knowledge of this situation) }\end{array}$ & 7.6 & & & \\
\hline & $\begin{array}{l}\text { Knowledge of sale of drugs } \\
\text { (\% of population that reported } \\
\text { having knowledge of this situ- } \\
\text { ation) }\end{array}$ & 6.7 & & & \\
\hline & $\begin{array}{l}\text { Knowledge of frequent robber- } \\
\text { ies and assaults (perception) }\end{array}$ & 7.5 & & & \\
\hline \multirow{5}{*}{$\begin{array}{l}\text { Criminal activity } \\
\text { and violence }\end{array}$} & Robbery with violence (Freq.) & 7.5 & \multirow{5}{*}{6.94} & \multirow{5}{*}{$\begin{array}{l}\text { They correlate with drug } \\
\text { trafficking and use }\end{array}$} & \multirow{5}{*}{$\begin{array}{l}\text { Incidencia delictiva del fuero } \\
\text { común (SEGOB, 2017) }\end{array}$} \\
\hline & Theft without violence (Freq.) & 6.7 & & & \\
\hline & Homicides (Freq.) & 6.8 & & & \\
\hline & Kidnappings (Freq.) & 6.9 & & & \\
\hline & Sex offenses/rapes (Freq.) & 6.8 & & & \\
\hline \multirow{4}{*}{$\begin{array}{l}\text { Volume of drug } \\
\text { seizures }\end{array}$} & Marijuana seizures (Tons.) & 8.1 & \multirow{4}{*}{8.1} & \multirow{4}{*}{$\begin{array}{l}\text { They are evidence of great- } \\
\text { er exposure in the area }\end{array}$} & \multirow{4}{*}{$\begin{array}{l}\text { Incidencia delictiva por en- } \\
\text { tidad federativa (SEGOB, } \\
2017 \text { ) }\end{array}$} \\
\hline & Cocaine seizures (Tons.) & 8.1 & & & \\
\hline & Heroin seizures (Tons.) & 8.1 & & & \\
\hline & Psychotropic seizures (units) & 8.1 & & & \\
\hline
\end{tabular}

indicators from being overrepresented by having a greater number of indicators than others, the risk rating of the indicators was averaged within each category. Based on these ratings, the values of the indicators were weighted and transformed, so that the parameters would be equivalent, even though the measurement units (persons, tons of drugs, etc.) varied. Each indicator was transformed on the basis of the weighted importance assigned, so that the maximum value obtained had the maximum value of the weighted importance assigned, based on a rule of 3 , although in the case of categorical variables, such as belonging to a metropolitan area, a fixed weight was assigned for those cases and zero for those which did not belong to metropolitan areas. The sum of these scores was used to obtain a Macrosocial Risk Index for Drug Use (MRIDU) for each municipality or delegation.

Lastly, the risk level was estimated based on the number of standard deviations of the indices with respect to the average. Thus, municipalities with scores above two standard deviations were codified as Very High risk, those with between one and two deviations were coded as High risk, scores located between the average and one deviation corresponded to municipalities with Medium High risk and the same was done with scores below the average. In this case, the categories corresponded to the Medium Low, Low and, Very Low risk levels.

\section{RESULTS}

Of the 426 municipalities or delegations with over 50000 inhabitants, 16 were identified as having a Macrosocial Risk Index of Drug Use corresponding to a Very High level (MRIDU greater than 51.68), 48 as having a High level (MRIDU of 46.38 to 51.68), 119 as having a medium high risk level (MRIDU of 41.12 to 46.36 ), 174 as having a medium low risk level (MRIDU of 35.79 to 41.05 ), and 68 as having a low risk level (MRIDU of 30.56 to 35.74 ), while just one municipality was classified with a very low risk level (MRIDU of 29.59) (Table 2).

Four municipalities in Baja California (Tijuana, Playas de Rosarito, Mexicali, and Ensenada), four Mexico City boroughs (Cuauhtémoc, Iztapalapa, Gustavo A. Madero, and Miguel Hidalgo), three municipalities in Sonora (San Luis Río Colorado, Puerto Peñasco, and Agua Prieta), two in Jalisco (Guadalajara and Puerto Vallarta), one in Nuevo León (Monterrey), one in Guerrero (Acapulco) and one in Chihuahua (Ciudad Juárez) were identified as being at very high risk (Table 2). Likewise, among the municipalities and boroughs with a high-risk level, 13 were identified in the State of Mexico, seven in Sonora, six in Mexico City, three in Tamaulipas, and two in each of the following states: Jalisco, Nuevo León, Chihuahua, Michoacán, Guanajuato, and Quintana Roo (Table 2). 
Table 2

Index of macrosocial risk of drug use (IRMCD) in municipalities and delegations in Mexico*

\begin{tabular}{|c|c|c|c|c|c|c|c|c|c|}
\hline & $\begin{array}{l}\text { Municipality } \\
\text { or borough }\end{array}$ & State & MRIDU & Risk level & & $\begin{array}{l}\text { Municipality } \\
\text { or borough }\end{array}$ & State & MRIDU & Risk level \\
\hline 1 & Tijuana & Baja California & 63.95 & Very high & 46 & Nuevo Laredo & Tamaulipas & 47.78 & High \\
\hline 2 & Cuauhtémoc & Cd. de México & 60.76 & Very high & 47 & Salinas Victoria & Nuevo León & 47.70 & High \\
\hline 3 & Guadalajara & Jalisco & 58.77 & Very high & 48 & $\begin{array}{l}\text { Valle de Chalco } \\
\text { Solidaridad }\end{array}$ & México & 47.69 & High \\
\hline 4 & Monterrey & Nuevo León & 58.54 & Very high & 49 & Tlalpan & Cd. de México & 47.69 & High \\
\hline 5 & Playas de Rosarito & Baja California & 56.67 & Very high & 50 & Lázaro Cárdenas & Michoacán & 47.63 & High \\
\hline 6 & Mexicali & Baja California & 56.39 & Very high & 51 & Navojoa & Sonora & 47.54 & High \\
\hline 7 & Iztapalapa & Cd. de México & 56.36 & Very high & 52 & San Luis Potosí & San Luis Potosí & 47.52 & High \\
\hline 8 & Puerto Vallarta & Jalisco & 55.03 & Very high & 53 & Chihuahua & Chihuahua & 47.48 & High \\
\hline 9 & $\begin{array}{l}\text { San Luis Río } \\
\text { Colorado }\end{array}$ & Sonora & 54.47 & Very high & 54 & Huehuetoca & México & 47.38 & High \\
\hline 10 & Ensenada & Baja California & 54.39 & Very high & 55 & Torreón & Coahuila & 47.37 & High \\
\hline 11 & Gustavo A. Madero & Cd. de México & 54.12 & Very high & 56 & García & Nuevo León & 47.02 & High \\
\hline 12 & $\begin{array}{l}\text { Acapulco } \\
\text { de Juárez }\end{array}$ & Guerrero & 53.02 & Very high & 57 & Tejupilco & México & 46.93 & High \\
\hline 13 & Cd. Juárez & Chihuahua & 52.73 & Very high & 58 & Tlajomulco de Zúñiga & Jalisco & 46.78 & High \\
\hline 14 & Puerto Peñasco & Sonora & 52.70 & Very high & 59 & Los Cabos & $\begin{array}{l}\text { Baja California } \\
\text { Sur }\end{array}$ & 46.73 & High \\
\hline 15 & Agua Prieta & Sonora & 52.69 & Very high & 60 & $\begin{array}{l}\text { San Miguel } \\
\text { de Allende }\end{array}$ & Guanajuato & 46.69 & High \\
\hline 16 & Miguel Hidalgo & Cd. de México & 52.52 & Very high & 61 & Venustiano Carranza & Cd. de México & 46.63 & High \\
\hline 17 & Tecámac & México & 51.68 & High & 62 & Huatabampo & Sonora & 46.54 & High \\
\hline 18 & Hermosillo & Sonora & 51.47 & High & 63 & Iztacalco & Cd. de México & 46.43 & High \\
\hline 19 & Chalco & México & 51.44 & High & 64 & Tláhuac & Cd. de México & 46.38 & High \\
\hline 20 & Benito Juárez & Cd. de México & 51.31 & High & 65 & Pesquería & Nuevo León & 46.36 & Medium high \\
\hline 21 & $\begin{array}{l}\text { Benito Juárez } \\
\text { (Cancún) }\end{array}$ & Quintana Roo & 50.96 & High & 66 & Salamanca & Guanajuato & 46.30 & Medium high \\
\hline 22 & Tecate & Baja California & 50.89 & High & 67 & Cuautitlán Izcalli & México & 46.29 & Medium high \\
\hline 23 & Ecatepec de Morelos & México & 50.49 & High & 68 & Tultitlán & México & 46.27 & Medium high \\
\hline 24 & Guaymas & Sonora & 50.33 & High & 69 & $\begin{array}{l}\text { San Pedro } \\
\text { Tlaquepaque }\end{array}$ & Jalisco & 46.22 & Medium high \\
\hline 25 & Cajeme & Sonora & 50.29 & High & 70 & Empalme & Sonora & 46.21 & Medium high \\
\hline 26 & Querétaro & Querétaro & 50.19 & High & 71 & Azcapotzalco & Cd. de México & 46.17 & Medium high \\
\hline 27 & Nogales & Sonora & 50.03 & High & 72 & Chicoloapan & México & 46.07 & Medium high \\
\hline 28 & Coyoacán & Cd. de México & 49.76 & High & 73 & Álvaro Obregón & Cd. de México & 46.04 & Medium high \\
\hline 29 & Puebla & Puebla & 49.76 & High & 74 & Veracruz & Veracruz & 45.99 & Medium high \\
\hline 30 & Reynosa & Tamaulipas & 49.67 & High & 75 & San José del Rincón & México & 45.89 & Medium high \\
\hline 31 & $\begin{array}{l}\text { Tlalnepantla } \\
\text { de Baz }\end{array}$ & México & 49.41 & High & 76 & Irapuato & Guanajuato & 45.84 & Medium high \\
\hline 32 & Manzanillo & Colima & 49.23 & High & 77 & Almoloya de Juárez & México & 45.81 & Medium high \\
\hline 33 & Chimalhuacán & México & 48.84 & High & 78 & Tampico & Tamaulipas & 45.68 & Medium high \\
\hline 34 & Nezahualcóyotl & México & 48.76 & High & 79 & $\begin{array}{l}\text { Acambay de Ruíz } \\
\text { Castañeda }\end{array}$ & México & 45.55 & Medium high \\
\hline 35 & Guadalupe y Calvo & Chihuahua & 48.66 & High & 80 & Xochimilco & Cd. de México & 45.46 & Medium high \\
\hline 36 & Morelia & Michoacán & 48.61 & High & 81 & Río Bravo & Tamaulipas & 45.29 & Medium high \\
\hline 37 & Zumpango & México & 48.46 & High & 82 & Celaya & Guanajuato & 45.15 & Medium high \\
\hline 38 & Solidaridad & Quintana Roo & 48.45 & High & 83 & Villa Victoria & México & 45.14 & Medium high \\
\hline 39 & $\begin{array}{l}\text { Naucalpan } \\
\text { de Juárez }\end{array}$ & México & 48.22 & High & 84 & Ixtapaluca & México & 45.12 & Medium high \\
\hline 40 & León & Guanajuato & 48.22 & High & 85 & Atizapán de Zaragoza & México & 45.11 & Medium high \\
\hline 41 & Toluca & México & 48.12 & High & 86 & Cuernavaca & Morelos & 45.08 & Medium high \\
\hline 42 & La Paz & México & 48.05 & High & 87 & Poncitlán & Jalisco & 44.94 & Medium high \\
\hline 43 & Matamoros & Tamaulipas & 48.02 & High & 88 & Uruapan & Michoacán & 44.91 & Medium high \\
\hline 44 & Zapopan & Jalisco & 47.92 & High & 89 & Acámbaro & Guanajuato & 44.86 & Medium high \\
\hline 45 & Caborca & Sonora & 47.86 & High & 90 & $\begin{array}{l}\text { San Felipe } \\
\text { del Progreso }\end{array}$ & México & 44.83 & Medium high \\
\hline
\end{tabular}


Table 2

Index of macrosocial risk of drug use (IRMCD) in municipalities and delegations in Mexico (continued)

\begin{tabular}{|c|c|c|c|c|c|c|c|c|c|}
\hline & $\begin{array}{l}\text { Municipality } \\
\text { or borough }\end{array}$ & State & MRIDU & Risk level & & $\begin{array}{l}\text { Municipality } \\
\text { or borough }\end{array}$ & State & MRIDU & Risk level \\
\hline 91 & Tecomán & Colima & 44.64 & Medium high & 138 & Tuxtla Gutiérrez & Chiapas & 42.81 & Medium high \\
\hline 92 & Salvatierra & Guanajuato & 44.62 & Medium high & 139 & Ayala & Morelos & 42.81 & Medium high \\
\hline 93 & Nicolás Romero & México & 44.58 & Medium high & 140 & Cadereyta Jiménez & Nuevo León & 42.78 & Medium high \\
\hline 94 & El Marqués & Querétaro & 44.58 & Medium high & 141 & Apodaca & Nuevo León & 42.77 & Medium high \\
\hline 95 & Zihuatanejo de Azueta & Guerrero & 44.40 & Medium high & 142 & Comonfort & Guanajuato & 42.73 & Medium high \\
\hline 96 & Etchojoa & Sonora & 44.37 & Medium high & 143 & San Felipe & Guanajuato & 42.70 & Medium high \\
\hline 97 & Chapala & Jalisco & 44.26 & Medium high & 144 & Gómez Palacio & Durango & 42.69 & Medium high \\
\hline 98 & Moroleón & Guanajuato & 44.25 & Medium high & 145 & Villahermosa & Tabasco & 42.69 & Medium high \\
\hline 99 & $\begin{array}{l}\text { Cuajimalpa } \\
\text { de Morelos }\end{array}$ & Cd. de México & 44.22 & Medium high & 146 & Lagos de Moreno & Jalisco & 42.66 & Medium high \\
\hline 100 & $\begin{array}{l}\text { Santa Cruz } \\
\text { de Juventino Rosas }\end{array}$ & Guanajuato & 44.05 & Medium high & 147 & Villa de Allende & México & 42.65 & Medium high \\
\hline 101 & Aguascalientes & Aguascalientes & 44.03 & Medium high & 148 & $\begin{array}{l}\text { Coacalco } \\
\text { de Berriozábal }\end{array}$ & México & 42.62 & Medium high \\
\hline 102 & $\begin{array}{l}\text { La Magdalena } \\
\text { Contreras }\end{array}$ & Cd. de México & 44.02 & Medium high & 149 & Tonalá & Jalisco & 42.61 & Medium high \\
\hline 103 & Uriangato & Guanajuato & 43.99 & Medium high & 150 & Huixquilucan & México & 42.58 & Medium high \\
\hline 104 & Guadalupe & Nuevo León & 43.98 & Medium high & 151 & San José Iturbide & Guanajuato & 42.58 & Medium high \\
\hline 105 & Pénjamo & Guanajuato & 43.89 & Medium high & 152 & Zinacantepec & México & 42.57 & Medium high \\
\hline 106 & El Alto & Jalisco & 43.86 & Medium high & 153 & Jiutepec & Morelos & 42.50 & Medium high \\
\hline 107 & Milpa Alta & Cd. de México & 43.84 & Medium high & 154 & Santiago Tuxtla & Veracruz & 42.49 & Medium high \\
\hline 108 & Puruándiro & Michoacán & 43.80 & Medium high & 155 & Hidalgo del Parral & Chihuahua & 42.40 & Medium high \\
\hline 109 & Cozumel & Quintana Roo & 43.78 & Medium high & 156 & Atotonilco el Alto & Jalisco & 42.37 & Medium high \\
\hline 110 & $\begin{array}{l}\text { Ixtlahuacán } \\
\text { de los Membrillos }\end{array}$ & Jalisco & 43.75 & Medium high & 157 & San Juan del Río & Querétaro & 42.35 & Medium high \\
\hline 111 & Temascalcingo & México & 43.74 & Medium high & 158 & Temixco & Morelos & 42.30 & Medium high \\
\hline 112 & San Fernando & Tamaulipas & 43.71 & Medium high & 159 & Chilapa de Álvarez & Guerrero & 42.23 & Medium high \\
\hline 113 & Acolman & México & 43.70 & Medium high & 160 & Texcoco & México & 42.22 & Medium high \\
\hline 114 & La Barca & Jalisco & 43.67 & Medium high & 161 & Ameca & Jalisco & 42.21 & Medium high \\
\hline 115 & Saltillo & Coahuila & 43.64 & Medium high & 162 & Valle de Bravo & México & 42.19 & Medium high \\
\hline 116 & Cuautla & Morelos & 43.54 & Medium high & 163 & Ixtlahuaca & México & 42.16 & Medium high \\
\hline 117 & Colima & Colima & 43.54 & Medium high & 164 & Tepatitlán de Morelos & Jalisco & 42.04 & Medium high \\
\hline 118 & Poza Rica de Hidalgo & Veracruz & 43.53 & Medium high & 165 & Silao de la Victoria & Guanajuato & 42.04 & Medium high \\
\hline 119 & Oaxaca de Juárez & Oaxaca & 43.50 & Medium high & 166 & Jiquipilco & México & 41.95 & Medium high \\
\hline 120 & Las Choapas & Veracruz & 43.49 & Medium high & 167 & Zamora & Michoacán & 41.93 & Medium high \\
\hline 121 & Altamira & Tamaulipas & 43.49 & Medium high & 168 & Victoria & Tamaulipas & 41.79 & Medium high \\
\hline 122 & Camargo & Chihuahua & 43.40 & Medium high & 169 & Apaseo el Alto & Guanajuato & 41.75 & Medium high \\
\hline 123 & Mazatlán & Sinaloa & 43.34 & Medium high & 170 & Metepec & México & 41.53 & Medium high \\
\hline 124 & Tultepec & México & 43.33 & Medium high & 171 & Amealco de Bonfil & Querétaro & 41.50 & Medium high \\
\hline 125 & Ixhuatlán de Madero & Veracruz & 43.25 & Medium high & 172 & Rioverde & San Luis Potosí & 41.49 & Medium high \\
\hline 126 & Ocotlán & Jalisco & 43.20 & Medium high & 173 & Santa Catarina & Nuevo León & 41.48 & Medium high \\
\hline 127 & Ramos Arizpe & Coahuila & 43.18 & Medium high & 174 & Ciudad Madero & Tamaulipas & 41.48 & Medium high \\
\hline 128 & General Escobedo & Nuevo León & 43.16 & Medium high & 175 & Córdoba & Veracruz & 41.42 & Medium high \\
\hline 129 & Juárez & Nuevo León & 43.15 & Medium high & 176 & $\begin{array}{l}\text { San Juan } \\
\text { de los Lagos }\end{array}$ & Jalisco & 41.42 & Medium high \\
\hline 130 & San Luis de la Paz & Guanajuato & 43.11 & Medium high & 177 & General Zuazua & Nuevo León & 41.38 & Medium high \\
\hline 131 & Coatzacoalcos & Veracruz & 43.04 & Medium high & 178 & Apatzingán & Michoacán & 41.37 & Medium high \\
\hline 132 & Xochitepec & Morelos & 43.04 & Medium high & 179 & Othón PBlanco & Quintana Roo & 41.33 & Medium high \\
\hline 133 & Tapachula & Chiapas & 42.93 & Medium high & 180 & Abasolo & Guanajuato & 41.22 & Medium high \\
\hline 134 & Cuauhtémoc & Chihuahua & 42.88 & Medium high & 181 & Xilitla & San Luis Potosí & 41.19 & Medium high \\
\hline 135 & Arandas & Jalisco & 42.87 & Medium high & 182 & Guanajuato & Guanajuato & 41.19 & Medium high \\
\hline 136 & Encarnación de Díaz & Jalisco & 42.84 & Medium high & 183 & La Piedad & Michoacán & 41.12 & Medium high \\
\hline 137 & Yuriria & Guanajuato & 42.84 & Medium high & & & & & \\
\hline
\end{tabular}

Note: *Only municipalities with a Very high, High and Medium high-risk level are included. 


\section{DISCUSSION AND CONCLUSION}

As can be seen, a significant number of municipalities in the country (64) have macrosocial conditions that presumably place their populations at a high or very high risk of substance use. They can therefore be considered key planning objectives for setting up care units for drug use. It is worth noting that factors such as the location of a municipality on a drug trafficking or production route (volume of drug seizures), state prevalences of use in the student population, presence of places where alcohol is sold, and inequality among the population were weighted by the participating experts as the macrosocial factors with the greatest risk of drug use, while population variables had the lowest weighting.

In this respect, one can say that at least one factor in each of the different types of indicators considered had a decisive influence on the macrosocial risk index obtained. In other words, those that have a direct relationship with use, in this case; state prevalence of use in the student population; those with a more or less direct causal relationship such as sites that have an impact on the supply of alcohol or other substances; those that involve an associative or correlational relationship with use, in this case, the perception of easy access to substances (knowledge of sale and use in the street) and structural factors, specifically those that denote conditions of inequality among the population, such as a low human development index and high Gini coefficient.

This study has limitations that deserve comment to facilitate the correct interpretation of results. First of all, it should be recalled that the data used are drawn from information sources with varying time scales and were collected for different purposes from those of this project. However, due to the lack of a single source of information, it was decided to use the most up to date available records. At the same time, although information was collected using an electronic card with the aim of incorporating new technologies into the research processes, using conventional instruments in a physical format or a faceto-face strategy for data collection could yield different results. Lastly, it is important to note that this diagnosis has a municipal scope and cannot provide data at the local level, and must therefore be complemented by other studies. Other diagnoses are therefore required to identify the areas of greatest risk for drug use within the municipality. An example of studies of this kind in Mexico is the Basic Target Community Study (BTCS), developed at Centros de Integración Juvenil, which identifies care needs at the local level based on area trips, as well as interviews with key informants, in order to obtain information on areas with the greatest care needs (Centros de Integración Juvenil, 2013). However, one limitation of this study is that, given its internal nature, it is only conducted in municipalities where this institution has care units. It would also be useful to conduct studies to determine the accessibility of services, both in the economic sense and about their geographical location, in order to facilitate treatment for those who so require.

\section{Funding}

None.

\section{Conflict of interest}

The authors declare they have no conflict of interest.

\section{REFERENCES}

Awad-Núñez, S., González-Cancelas, N., \& Camarero-Orive, A. (2014). Application of a model based on the use of DELPHI methodology and Multicriteria Analysis for the assessment of the quality of the Spanish Dry Ports location. ProcediaSocial and Behavior Science, 162, 42-50. doi: 10.1016/j.sbspro.2014.12.184

Boulkedid, R., Abdoul, H., Loustau, M., Sibony, O., \& Alberti, C. (2011). Using and reporting the Delphi method for selecting healthcare quality indicators: A systematic review. PLoS ONE, 6(6), e20476. doi: 10.1371/journal.pone.0020476

Centros de Integración Juvenil. (2013). Estudio Básico de Comunidad Objetivo 2013. México: Centros de Integración Juvenil, A.C.

García, V. R., Rodríguez, S. E., Córdova, A. J., \& Fernández, M. C. (2016). Diagnóstico macrosocial de riesgo del consumo de drogas en México. Acta de Investigación Psicológica, 6(3), 2516-2526. doi: 10.1016/j.aipprr.2016.11.005

García, M. \& Suárez, M. (2013). El método Delphi para la consulta a expertos en la investigación científica. Revista Cubana de Salud Pública, 39(29), 253-267. Retrieved from: http://scielo.sld.cu/pdf/rcsp/v39n2/spu07213.pdf

Hawkins, J., Catalano, R., \& Miller, J. (1992). Risk and protective factors for alcohol and other drug problems in adolescence and early adulthood: Implications for substance abuse preventive. Psychological Bulletin, 112(1), 64-105. doi: 10.1037/0033-2909.112.1.64

Instituto Nacional de Psiquiatría Ramón de la Fuente Muñiz, Comisión Nacional Contra las Adicciones, \& Secretaría de Salud. (2015). Encuesta Nacional de Consumo de Drogas en Estudiantes 2014: Reporte de Drogas. México: INPRFM. Retrieved from: http://www.conadic.salud.gob.mx/pdfs/investigacion/ENCODE_ DROGAS_2014.pdf

Instituto Nacional de Psiquiatría Ramón de la Fuente Muñiz, Instituto Nacional de Salud Pública, \& Secretaría de Salud. (2012). Encuesta Nacional de Adicciones 2011: Reporte de Drogas. México: INPRFM. Retrieved from: http://www. conadic.salud.gob.mx/pdfs/ENA_2011_DROGAS_ILICITAS_.pdf

Salinas, E., Domínguez, A., Zapata, R., Díaz-Negrete, D., Quintanilla, J., \& Guisa, V. M. (1997). Riesgos Macrosociales de Farmacodependencia a Nivel Municipal y Red Estratégica de Atención en México. Plan Rector Institucional 1988-2000. México: Centros de Integración Juvenil A. C.

Santos, A. \& Paiva, V. (2007). Vulnerability to HIV: Tourism and the use of alcohol and other drugs. Revista de Saúde Pública, 41(2), 80-86. Retrieved from: https://www.ncbi.nlm.nih.gov/pubmed/18094790

Secretaría de Salud. (2009). Encuesta Nacional de Adicciones 2008 (ENA, 2008). México: Consejo Nacional contra las Adicciones, Instituto Nacional de Psiquiatría Ramón de la Fuente Muñiz, Instituto Nacional de Salud Pública, Dirección General de Epidemiología, Dirección General de Información en Salud, Centros de Integración Juvenil. Retrieved from: http://www.conadic. salud.gob.mx/pdfs/ena08/ENA08_NACIONAL.pdf

Taylor-Powell, E. (2002). Quick tips collecting group data: Delphi technique. Madison: University of Wisconsin. Retrieved from: http://www.uwex.edu/ces/ pdande/resources/pdf/Tipsheet4.pdf

United Nations \& International Drug Control Programme. (1998). Economic and social consequences of drug abuse and illicit trafficking. Retrieved from: https://www.ncjrs.gov/App/Publications/abstract.aspx?ID=195521

Zhang, X., Martínez-Donate A. P., Nobles, J., Hovell, M. F., Rangel, M. G., \& Rhoads, N. M. (2015). Substance use across different phase of the migration process: A survey of Mexican migrants flows. Journal of Immigrant and Minority health, 17(6), 1746-1757. doi: 10.1007/s10903-014-0109-5 